\title{
GESTÃO AMBIENTAL DE ATRATIVOS TURÍSTICOS NATURAIS DA APA CAVERNA DO MAROAGA, PRESIDENTE FIGUEIREDO/AM
}

\author{
João Rodrigo Leitão dos Reis \\ Programa de Pós-Graduação em Ciências Florestais e Ambientais - UFAM \\ jrlreis@gmail.com \\ Julio César Rodríguez Tello \\ jucerote@hotmail.com
}

\begin{abstract}
Resumo
O artigo apresenta uma análise do estado da gestão ambiental de atrativos turísticos naturais da Área de Proteção Ambiental (APA) Caverna do Maroaga, com aplicação dos métodos da pesquisa exploratória, por Representação Social e a utilização da técnica de Análise de Conteúdo. Como resultado detectou-se que os fatores que tornam a gestão dos atrativos da APA um desafio são a ausência de capacitação, apoio técnico e fomento aos proprietários, bem como, a inexistência de regulamentação de uso público, que envolva o licenciamento, fiscalização e monitoramento ambiental
\end{abstract}

Palavras-chave: Áreas Naturais, Gestão Ambiental, APA Caverna do Maroaga, DAFO

\section{Abstract}

The article introduces an analysis of the state of the environmental management situation of natural tourist attractions in the Maroaga Cave Environmental Protection Area (APA), applying exploratory research methods by Social Representatives and using Content Analysis technique. As a result, the factors detected that made the management of the APA attractions a challenge are the lack of qualification, technical support, and resources granted by the owners, as well as the inexistence of public regulations, which involve licensing, inspection, and environmental monitoring.

Key Words : Natural Areas, Environmental Management, APA Maroaga Cave, SWOT

\section{INTRODUÇÃO}

A gestão de áreas naturais para o turismo é uma das premissas básicas para implementação de áreas protegidas, seja para o uso público ou interpretação e educação ambiental. No entanto, as distintas formas de uso dessas áreas quando inseridas em Áreas de Proteção Ambiental, que possuem co-existência de áreas privadas e públicas em seu interior, gera conflitos quanto às medidas mais apropriadas para a gestão ambiental de seus atributos naturais. Tal fato provoca, perante a ausência de atuação do órgão gestor da unidade de conservação, a exploração comercial e incorporação de áreas naturais aos usuários do turismo de massa, responsável pela degradação desses espaços e pela minimização de seu potencial de uso.

Salienta-se que o atrativo é o elemento que desencadeia o processo turístico. Qualquer atrativo, recurso ou elemento territorial, patrimonial, infraestrutural ou de qualquer outro tipo, apresentado em sua forma natural, com maior ou menor grau de tangibilidade, que aparece em um território, convenientemente tratado e agrupado a uma série de elementos, é capaz de colocar-se a serviço da satisfação turística (Valls, 2006). O planejamento é um dos principais instrumentos que o Estado tem para estimular o desenvolvimento da atividade turística. O objetivo do planejamento de destinos turísticos é transformar recursos em produtos turísticos e produtos em ofertas competitivas (VIGNATI, 2008).

No entanto, sem regulamentação apropriada, os problemas de sobre-exploração e, particularmente, de degradação ecológica podem se intensificar com o desenvolvimento do ecoturismo (MIECZKOWSKI, 1995 apud WEARING; NEIL, 2001). Dessa forma, os administradores de áreas protegidas precisam 
avaliar que tipo de turismo é mais adequado para cada área, com o objetivo de construir uma estratégia que atinja o nível desejado (BOO, 1995), por meio de uma abordagem multidisciplinar, com planejamento sustentável e cuidadoso, tanto físico como gerencial, aliado a formulação de diretrizes e regulamentos que garantam seu funcionamento adequado, através de um sistema introspectivo para alcançar seus objetivos (CEBALLOS-LASCURÁIN, 1995).

De acordo com Wearing \& Neil (2001), o turismo não tem correspondido às altas expectativas, já que seus benefícios são, muitas vezes, limitados pelos significativos impactos que produz sobre o ecossistema e as comunidades locais, sendo estimulado pelo governo ou pela indústria sem uma necessária estratégia global, sem atenção adequada à estrutura legislativa, sem consulta ou a inclusão das comunidades locais e sem projetos eficazes de manejo da área de proteção.

De acordo com Ceballos-Lascuráin (1995), instalações físicas adequadas nas áreas naturais e em suas proximidades são fundamentais para o desenvolvimento do ecoturismo. Dessa forma, planejamento, projeto e critérios de construção adequados devem ser aplicados, a fim de minimizar o impacto sobre o meio ambiente fornecer certo grau de auto-suficiência funcional e contribuir para a melhoria da qualidade da experiência do visitante.

A experiência tem mostrado que a participação de agentes locais, assim como a articulação entre as três esferas de governo (Municípios, Estados e União), é vital para o sucesso de iniciativas de conservação (BENSUSAN, 2006). Portanto, a viabilidade, em longo prazo, de uma área protegida depende de sua integração ecológica, social, econômica e política à região que a cerca (SCHERL et al. 2006).

O processo de criação, implementação e gestão de UC no Brasil segue os procedimentos da Lei 9.985, de 18 de julho de 2000, que instituiu o Sistema Nacional de Unidades de Conservação da Natureza (SNUC). Além dos decretos regulamentadores dela, resultando em um processo que norteia a gestão e definição de mecanismos para a efetividade desses espaços. O Estado do Amazonas em conformidade com o SNUC instituiu o Sistema Estadual de Unidades de Conservação (SEUC), Lei Complementar no . 53, de 05 de junho de 2007.

No Amazonas, as Unidades de Conservação estaduais representam cerca de 12,2\% do seu território, compreendidas em 10 de Proteção Integral e 31 de uso sustentável, somando 41 unidades (Amazonas, 2009). Segundo a Lei Complementar n. 53, de 05 de junho de 2007, que instituiu o Sistema Estadual de Unidades de Conservação do Amazonas (SEUC-AM), as UC são "espaços territoriais com características naturais relevantes e seus recursos ambientais, incluindo as águas jurisdicionais, legalmente instituído pelo Poder Público, com objetivos de conservação e de desenvolvimento sustentável das comunidades tradicionais, com limites definidos, sob regime especial de administração, ao qual se aplicam garantias adequadas de proteção".

O foco da pesquisa foi a Área de Proteção Ambiental (APA) estadual "Caverna do Maroaga", UC de uso sustentável, localizada no município de Presidente Figueiredo/AM. A APA está prevista no artigo $16^{\circ}$ da Lei Complementar $n^{\circ}$. 53/2007 que instituiu o SEUC .

A relativa facilidade de criação de APA, que prescinde de expropriação, realizada, muitas vezes, desvinculada dos propósitos de conservação, bem como a maneira que vem sendo administrada, torna essa categoria um instrumento desacreditado (Cabral e Souza, 2005). Porém deve-se considerar a possibilidade de aplicação de rígidas restrições de uso e ocupação da terra, motivadas pela identificação de locais que apresentam fragilidade ambiental e, também para a efetiva proteção dos mesmos.

As APA apresentam uma perspectiva preservacionista com forte aval político, onde a proliferação de sua instituição teria como uma de suas finalidades ampliarem as estatísticas de UC, apesar de possuírem, em grande parte, decreto e de plano de manejo inoperantes, uma vez que sua efetividade depende 
da conscientização e vontade dos legítimos proprietários de suas terras em aceitarem restrições de uso (PÁDUA, 2001).

Entretanto, cabe destacar que as UC apresentam papel fundamental nos locais visitados. Essas unidades concentram grande número de atrativos, são vistas como um importante chamariz, e podem estimular e abrigar mecanismos efetivamente participativos de gestão e monitoramento do ecoturismo e do desenvolvimento territorial (TAKAHASHI et al. 2002).

Para isso, deve-se efetuar a confecção do documento de planejamento, conhecido como plano de uso público, cujo conteúdo resulta de uma avaliação abrangente da base de recursos naturais e culturais da área. Seus componentes determinarão as pressões, suas fontes e as ameaças reais à integridade do patrimônio natural e cultural da área, bem como, as estratégias para reduzir tais ameaças (DRUMM; MOORE, 2002).

Nesse sentido, diversos estudos foram realizados sobre visitação em áreas naturais, porém grande parte focalizada na deteç̧ão de impactos ambientais em decorrência do turismo e sobre a capacidade de carga ou suporte das áreas para atendimento a demanda turística, sem trabalhar diretamente com a percepção dos gestores públicos e privados dos atrativos. Destacam-se também estudos sobre a caracterização da visitação, identificação do perfil, percepção e preferências dos visitantes e sobre a detecção dos impactos ocasionados pelo turismo em áreas naturais, tendo como exemplos os trabalhos desenvolvidos por Takahashi (2004) e Takahashi e Milano (2002), que foram precursores desses estudos no Brasil. Soma-se a isso a pesquisa desenvolvida por Lobo (2008) sobre o ecoturismo e percepção de impactos socioambientais sob a ótica de turistas no Parque Estadual Turístico do Alto do Ribeira.

Na região da Área de Proteção Ambiental (APA) Caverna do Maroaga são raros os estudos desenvolvidos junto aos proprietários/gestores de áreas naturais com ou sem proteção oficial buscando saber sua visão sobre o estado do uso público desses locais (estado de conservação, administração da visitação, impactos ambientais etc). Além disso, na APA pesquisas voltadas para detecção da capacidade de carga ou de suporte dos locais são praticamente inexistentes.

No entanto, quanto ao diagnóstico ambiental das áreas pode-se citar a pesquisa desenvolvida por Gadelha e Alecrim (2006), onde detectaram e analisaram os impactos ambientais em três atrativos naturais (Cachoeira da Porteira, Cachoeira do Santuário e Caverna do Maroaga). Cabe salientar que um dos agravantes sobre os efeitos do turismo na APA Caverna do Maroaga, é o fato de não possuir plano de manejo e medidas de gestão e regulamento de uso público (capacidade de carga, controle de visitantes, etc) para as áreas naturais que abrange, podendo ser considerado a principal ameaça a integridade ambiental dos seus atrativos (SESSEGOLO et al. 2004, REIS; FREITAS, 2008).

Dessa maneira, nesse artigo é apresentada uma análise das medidas administrativas e de uso público, adotadas e em prática, no usufruto dos atrativos turísticos naturais APA Caverna do Maroaga sob a ótica dos seus proprietários, preenchendo a lacuna de informação existente quanto ao diagnóstico ambiental e turístico dessas áreas, com a identificação de demandas e a perspectiva de soluções envolvendo seus usuários diretos.

\section{MATERIAL E MÉTODOS}

\section{Área de Estudo}

A APA Caverna do Maroaga possui 374.700 ha, equivalente a 14\% do município de Presidente Figueiredo/AM. A UC está localizada entre as coordenadas geográficas $01^{\circ} 11^{\prime} 35^{\prime \prime}$ a $02^{\circ} 16^{\prime} 02^{\prime \prime}$ de latitude sul e 59 $17^{\prime} 24^{\prime \prime}$ a $60^{\circ} 25^{\prime} 12^{\prime \prime}$ de longitude oeste de Greenwich. Possui como limites a BR-174 (Oeste), 
a Reserva Indígena Waimiri-Atroari/Roraima (Norte), o Lago da Hidrelétrica de Balbina (Leste), o rio Uatumã (Sudeste) e rio Urubu (Sul). Na sua parte sul é cortada pela rodovia AM-240.

$\mathrm{Na}$ APA Caverna do Maroaga encontram-se áreas com atrativos naturais (Figura 1/Tabela 1) com ou sem uso turístico direto.

Tabela 1 - Denominação do Atrativo

\begin{tabular}{|c|c|c|c|c|}
\hline $\begin{array}{l}\text { Denominação } \\
\text { do atrativo }\end{array}$ & Perfil Administrativo & \multicolumn{2}{|c|}{ Coord.Geográficas } & Questão fundiária \\
\hline Caverna do Maroaga & $\begin{array}{l}\text { Influência da administração mu- } \\
\text { nicipal de Presidente Figueiredo }\end{array}$ & $02^{\circ} 03^{\prime} 2,56^{\prime \prime}$ & $59^{\circ} 58^{\prime} 10,4^{\prime \prime}$ & $\begin{array}{l}\text { Propriedades Privadas/ } \\
\text { Posse }\end{array}$ \\
\hline $\begin{array}{l}\text { Corredeira Sossego } \\
\text { da Pantera }\end{array}$ & Reserva não oficial & $2^{\circ} 02^{\prime} 33.1^{\prime \prime}$ & $59^{\circ} 50^{\prime} 58.3^{\prime \prime \prime}$ & Propriedade Privada \\
\hline $\begin{array}{l}\text { Cachoeira da Ma- } \\
\text { roca }\end{array}$ & Reserva não oficial & $02^{\circ} 45,3^{\prime \prime}$ & $59^{\circ} 51^{\prime} 40,6^{\prime \prime \prime}$ & Propriedade Privada \\
\hline $\begin{array}{l}\text { Cachoeira da Por- } \\
\text { teira }\end{array}$ & Reserva não oficial & $02^{\circ} 02^{\prime} 20.8^{\prime \prime}$ & $59^{\circ} 55^{\prime} 15.6^{\prime \prime \prime}$ & Propriedade privada \\
\hline $\begin{array}{l}\text { Cachoeira do San- } \\
\text { tuário }\end{array}$ & RPPN & $02^{\circ} 03^{\prime} 38.7^{\prime \prime}$ & $59^{\circ} 55^{\prime} 45.2^{\prime \prime \prime}$ & Propriedade Privada \\
\hline $\begin{array}{l}\text { Sítio Pedacinho do } \\
\text { Céu }\end{array}$ & Reserva não oficial & $02^{\circ} 02^{\prime} 53,6^{\prime \prime}$ & $\begin{array}{l}59^{\circ} 53 \\
14.3^{\prime \prime}\end{array}$ & Propriedade privada \\
\hline Cachoeira Maranata & Reserva não oficial & $01^{\circ} 55^{\prime} 12^{\prime \prime}$ & $59^{\circ} 56^{\prime} 55^{\prime \prime}$ & $\begin{array}{l}\text { Propriedade Privada/ } \\
\text { Posse }\end{array}$ \\
\hline $\begin{array}{l}\text { Cachoeira das Or- } \\
\text { quídeas }\end{array}$ & $\begin{array}{l}\text { Unidade de Conservação Mu- } \\
\text { nicipal }\end{array}$ & $02^{\circ} 02^{\prime} 07^{\prime \prime}$ & $60^{\circ}$ & Área pública \\
\hline $\begin{array}{l}\text { Parque Galo da } \\
\text { Serra }\end{array}$ & \multicolumn{3}{|l|}{ Unidade de Conservação Municipal } & Área pública \\
\hline ARIE das Aves & \multicolumn{3}{|l|}{ Unidade de Conservação Municipal } & Área pública e privada \\
\hline
\end{tabular}

\section{Método e etapas da pesquisa}

Foram utilizados os métodos da Pesquisa Exploratória de caráter quali-quantitativo. Esse tipo de investigação tem por objetivo conhecer a variável de estudo tal qual se apresenta, seu significado e o contexto onde ela se insere, originando a formação de questões ou um problema, com tripla finalidade: desenvolver hipóteses, aumentar a familiaridade do pesquisador com o ambiente, fato ou fenômeno e clarificar ou modificar conceitos (MARCONE, 2002).

Para a interpretação dos comportamentos dos atores sociais e suas relações com o meio ambiente foi utilizada a análise da Representação Social (BARDIN, 1977; Moscovici, 1978; Minayo, 1995; Abric, 2000), por meio da execução da técnica "Análise de Conteúdo" (BARDIN, 1977). Tal técnica possibilita a realização de pesquisa bibliográfica, documental e de campo, com aplicação de ferramentas de coleta de dados e informações (Marcone, 2002; Gressler, 2004; Santos, 2005; Marangoni, 2005).

A representação social é uma modalidade de conhecimento particular que tem por função a elaboração de comportamentos e a comunicação de indivíduos (Moscovici, 1978), não existe uma realidade objetiva a priori, mas sim que toda a realidade é representada, quer dizer, reapropriada pelo indivíduo ou pelo grupo, reconstruída no seu sistema cognitivo, integrada no sistema de valores, dependente de sua história e do contexto social e ideológico que o cerca (Abric, 2000), podem e devem ser analisadas a partir da compreensão das estruturas e dos comportamentos sociais (MINAYO, 1995). 
Para Bardin (1977), a análise de conteúdo é um conjunto de técnicas de análise das comunicações visando obter, por procedimentos, sistemáticos e objetivos de descrição do conteúdo das mensagens, indicadores (quantitativos ou não) que permitam a inferência de conhecimentos relativos às condições de produção/recepção (variáveis inferidas) destas mensagens. Possui diferentes fases, e organizam-se em torno de três pólos cronológicos (BARDIN, 1977): a pré-análise; a exploração do material, e o tratamento dos resultados, a inferência e a interpretação.

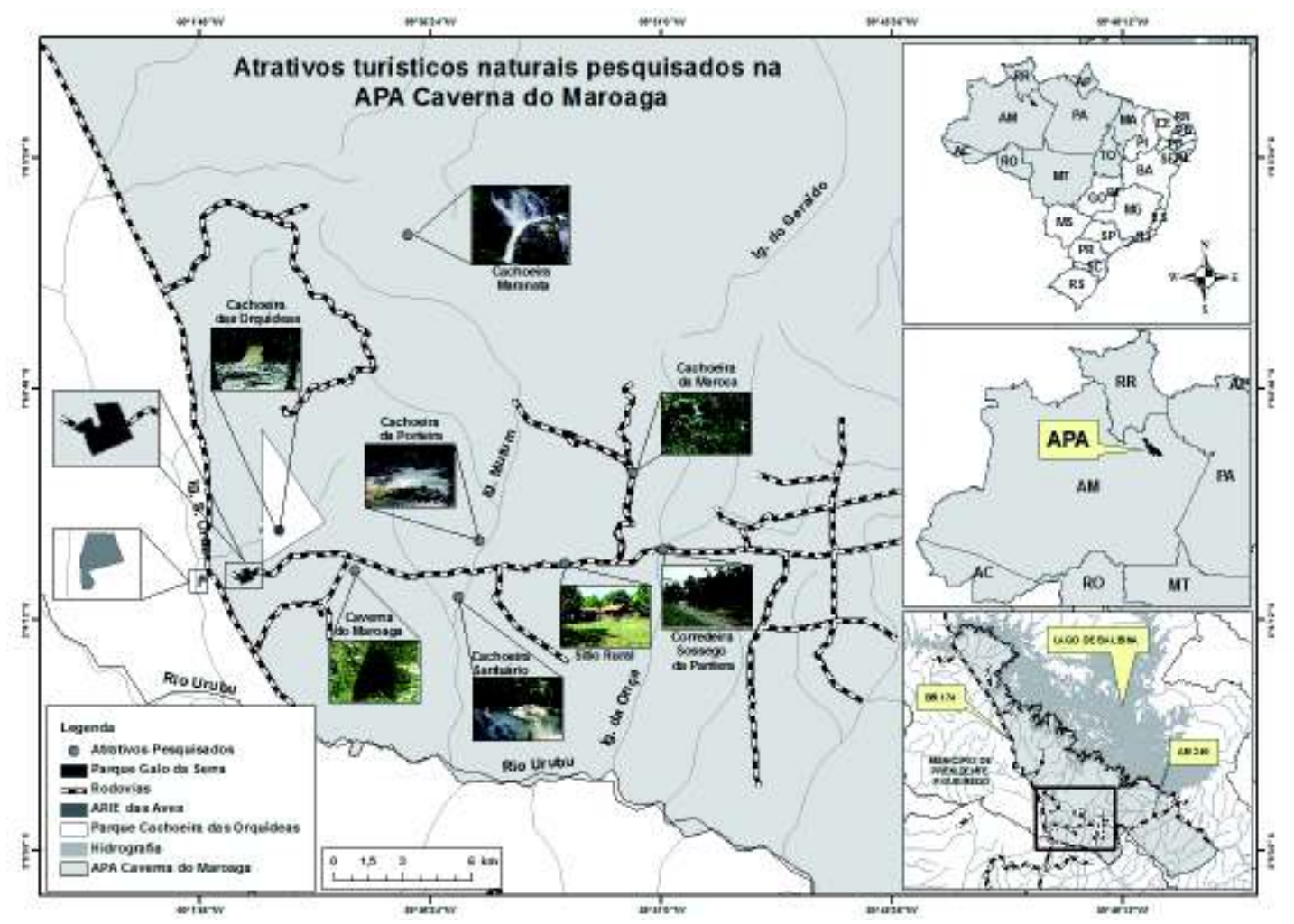

Figura 1 - Áreas naturais da APA Caverna do Maroaga visitadas.

Fonte: Reis, J. R. L. dos, 2010.

A técnica da entrevista tem como necessidade básica o registro de informações obtidas que poderá ser realizado por meio de anotações (MARANGONI, 2005) em roteiros pré-estabelecidos, ou seja, é um procedimento utilizado na investigação social, para a coleta ou para ajudar no diagnóstico ou no tratamento de um problema social (MARCONE, 2002).

No âmbito dessa pesquisa entende-se:

- Gestores de áreas naturais: são os proprietários, que podem ser dirigentes públicos, empresários/ empreendedores, operadores de turismo, comunitários e demais donos de reservas oficiais ou não e/ou de áreas privadas. Podem realizar atividades de recreação e/ou uso público ou particular, desenvolvimento de 
serviços de hospedagem, camping e de alimentação na área com a finalidade de arrecadação financeira, que complementa a renda familiar e serve para manutenção da área;

- Usuários de áreas naturais: são os proprietários/gestores, visitantes e comunitários.

Tendo como parâmetros à representatividade das amostras (BARDIN, 1977), foram selecionadas 10 (dez) áreas com atrativos naturais para realização de entrevista aos seus gestores, tendo como critério o uso turístico freqüente ou seletivo (Figura 2). As áreas foram escolhidas em virtude de estarem localizadas no entorno de rodovias e ramais/vicinais, inseridas nos limites geográficos da APA Caverna do Maroaga. Sendo assim, foram entrevistados indivíduos escolhidos entre adultos de todos os gêneros, tendo como único critério que fossem gestores dos locais. Para isso, não se enfatizou a forma de acesso, mas o perfil da área e quem a administra.

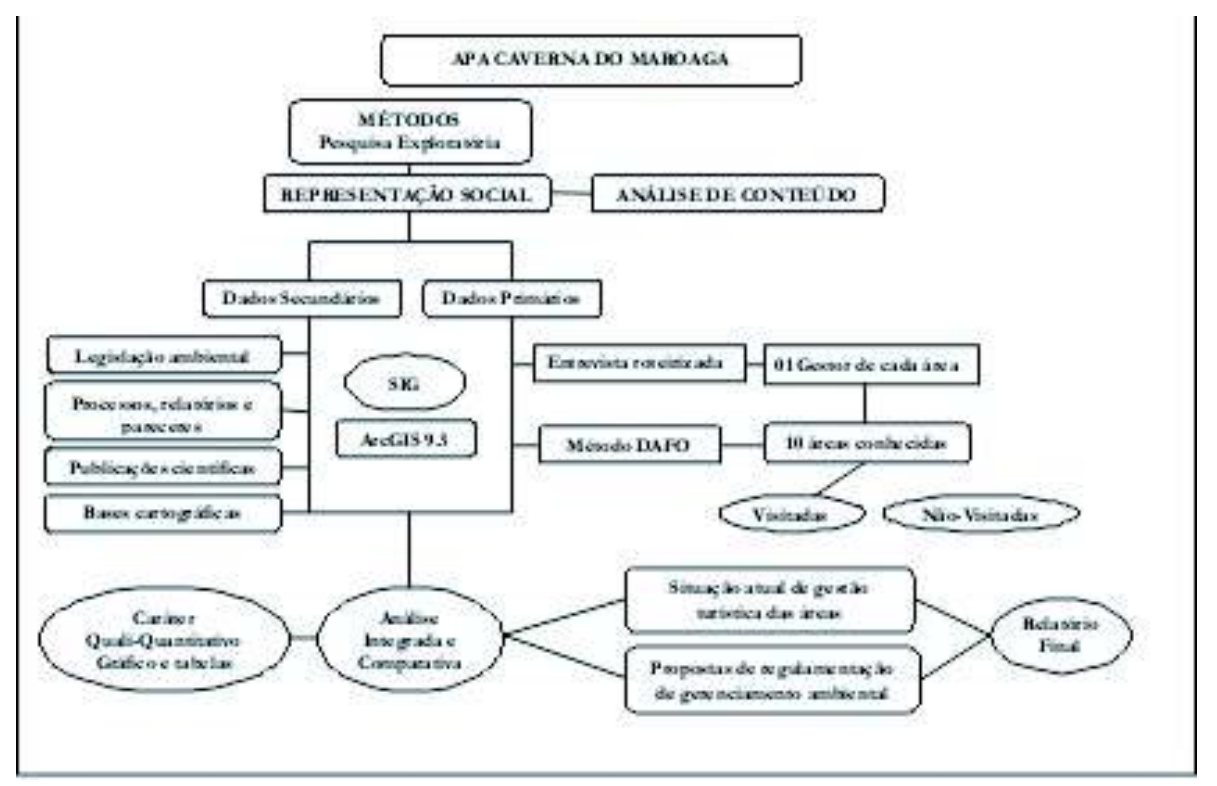

Figura 2 - Fluxograma da estratégia metodológica

O formulário de entrevista apresentou também uma tabela FOFA/DAFO (DRUMOND, 2002; FIDALGO, 2003), em inglês SWOT. A análise das fortalezas, oportunidades, fraquezas e ameaças (FOFA) é um método subjetivo de avaliar determinados contextos setorizados. Pode representar, se os fatores de avaliação forem bem identificados, uma excelente base para tomada de decisão em planejamento privado ou público (política pública). Diante da predominância de pontos fortes ou fracos e de oportunidades e ameaças, pode-se adotar estratégias (ou posturas estratégicas) que busquem a sobrevivência, manutenção, crescimento ou desenvolvimento da organização (Azevedo \& Costa, 2001), representada pelas áreas naturais pesquisadas.

Azevedo \& Costa (2001), apresentam o método de construção da Matriz de Avaliação de Fatores Externos e Internos (External Factor Evaluation - EFE e Internal Factor Evaluation - IFE), técnica da área de Administração usada para identificar fatores externos e internos que influenciam o comportamento 
da organização. É realizada com atribuição de valores para cada fator (pesos) com forma de sair da subjetividade. Pode ser usada tanto para complementar a análise SWOT como isoladamente.

Da mesma maneira, deve-se proceder em relação aos fatores internos da organização (falta de mão-deobra, falta de conhecimentos, dificuldades no manejo e controle das áreas, etc.). Chama-se, neste caso, de Matriz de Fatores Internos (IFE - Internal Factor Evaluation). Da mesma forma que com a Matriz EFE, a Matriz IFE serve para ajudar, ao evidenciar informações sobre os recursos disponíveis, na formulação de estratégias (e planejamento) com base no conhecimento dos fatores internos e externos da organização (AZEVEDO; COSTA, 2001).

A planilha FOFA de cada um dos 10 atrativos foi categorizada e hierarquizada conforme a freqüência das respostas dos entrevistados. O número de freqüências a cada quesito e também a relevância das respostas correspondeu ao peso que a ele foi aplicado. E, por conseguinte, a aplicação dos métodos para determinação de fatores internos e externos aos atrativos.

Por fim, foi realizada a análise integrada dos dados e informações por meio de matrizes de interação e listagem de controle de acordo com os métodos propostos por Santos (2004), no qual relaciona a informação obtida por leventamentos primários e secundários, por meio de gráficos, tabelas ou diagramas na estrutura de um modelo de interação (FIDALGO, 2003). Desta forma, a análise do conteúdo resultante dos formulários de entrevista foi realizada por meio da categorização dos elementos, a partir das variáveis pré-estabelecidas e tratados em percentual.

\section{RESULTADOS E DISCUSSÃO}

\section{As medidas administrativas e de uso público para o uso de áreas naturais}

a) Caracterização das áreas naturais

O controle e gestão ambiental de atrativos turísticos estão atrelados a adoção de medidas/normas de gestão e da implantação de infraestrutura básica, equipamentos específicos e recursos humanos nas Unidades de Conservação onde estão inseridos. Sob essa ótica, de acordo com os entrevistados, $90 \%$ dos atrativos visitados na APA Caverna do Maroaga possuem denominação oficial e $80 \%$ apresentam placas de identificação (Figura 3). Esse resultado é bastante satisfatório e é um dos aspectos de destaque para localização dos empreendimentos pelos visitantes. No entanto, alguns empreendimentos não apresentam o mínimo necessário para facilitar sua identificação.
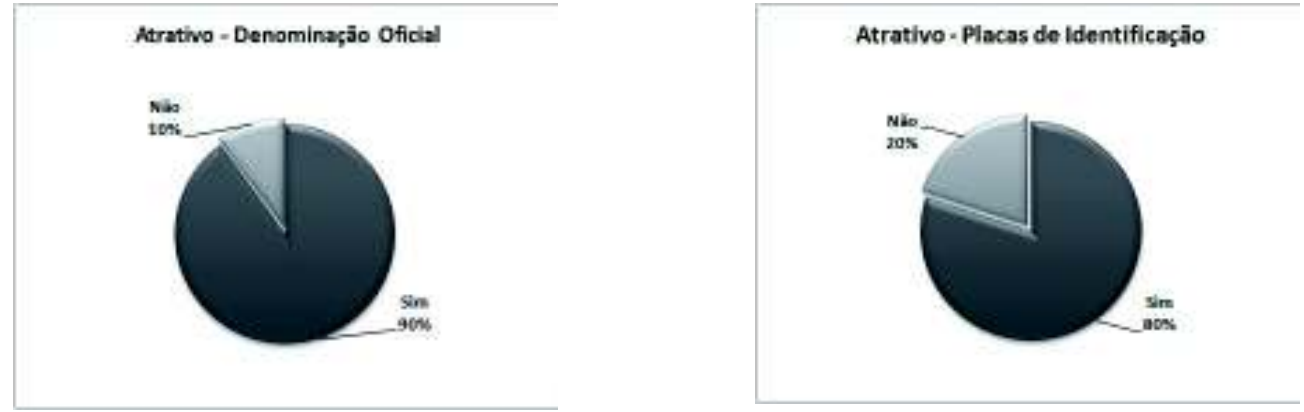

Figura 3 - Localização dos atrativos: a) Denominação oficial; e b) Placas de identificação. 
Segundo os entrevistados, grande parte dos atrativos está cadastrada no inventário turístico municipal $(70 \%)$ e estadual (60\%), enquanto que apenas 30\% foram cadastrados pela Secretaria Municipal de Turismo de Presidente Figueiredo (SEMTUR) (Figura 4 a). O envolvimento com a iniciativa privada é praticamente particularizada, pois apenas $20 \%$ dos entrevistados afirmam que o atrativo está inserido em pacotes de agências turísticas (Figura 4 b). Esses atrativos são a Caverna do Maroaga, símbolo turístico do município de Presidente Figueiredo, e a Cachoeira Santuário que possui contrato com uma agência de turismo de Manaus, além de ser o atrativo que possui melhor infraestrutura para estadia e alimentação do visitante.
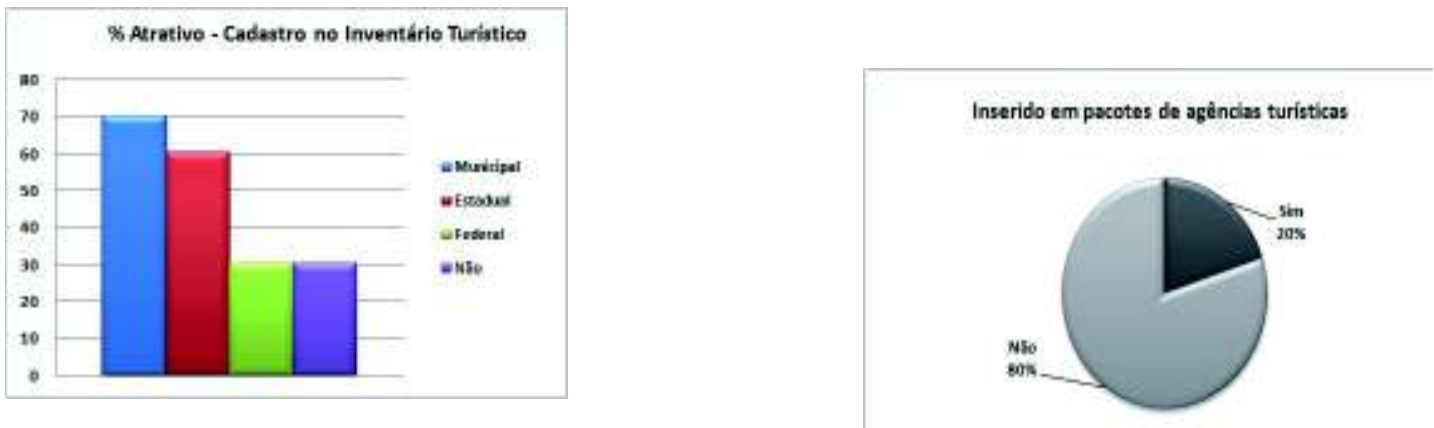

Figura 4 - Viabilidade da visitação nos atrativos: a) Cadastro no inventarı turıstıco; e b) Inserıdos em pacotes de agências turísticas.

A maior parte dos atrativos possuem até 15 anos de uso turístico (30\%), no entanto $10 \%$ dos entrevistados destacaram que alguns possuem até 25 anos de usufruto (Figura 5 a). É notório destacar que o impulso dado ao processo de colonização e aquisição e uso dessas áreas pelo turismo foi realizado com a abertura e posterior asfaltamento da BR 174 (iniciada em 1970) e AM 240.
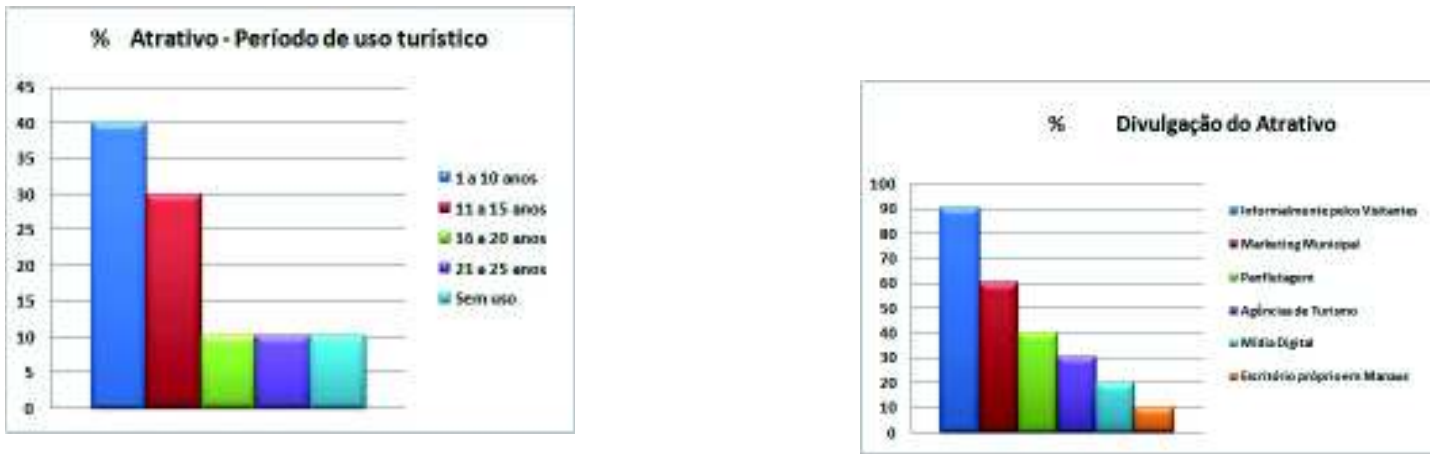

Figura 5 - Vitalidade dos atrativos: a) Período de uso turístico; e b) Divulgação do atrativo.

A divulgação dos atrativos ocorre grande parte de forma informal (90\%), sendo realizada principalmente pelos próprios usuários (Figura 5 b). No entanto, grande parte é auxiliada pela realização de propaganda pela Secretaria Municipal de Turismo de Presidente Figueiredo, com expedição de folderes 
divulgativos. Além disso, a planfletagem realizada pelos próprios proprietários ou mesmo agências de turismo, que utilizam as imagens dos atrativos como propaganda do referido município. Outro aspecto notório é a participação do uso da mídia digital, que além dos sites de orgãos de governo, há a utilização das imagens nas páginas de relacionamento pessoais (Blog’s, etc) construídas pelos visitantes.

b) Uso público das áreas

Quando indagados sobre a motivação dos visitiantes na frequência à área, os entrevitados vincularam a três aspectos (Figura 6 a): a) ao contato com a natureza (30\%), de forma genérica, considerando esse termo amplo e de grande associação a todos os elementos da paisagem e a sensação de bem-estar do visitante; b) aos atrativos propriadamente ditos, com destaque a cachoeiras, que são o principal alvo de visitação; e c) a existência de infraestrutura básica para maior comodidade do visitante (10\%). Observase que as tipologias de atrativos obtiveram cada uma 10\% de citação.
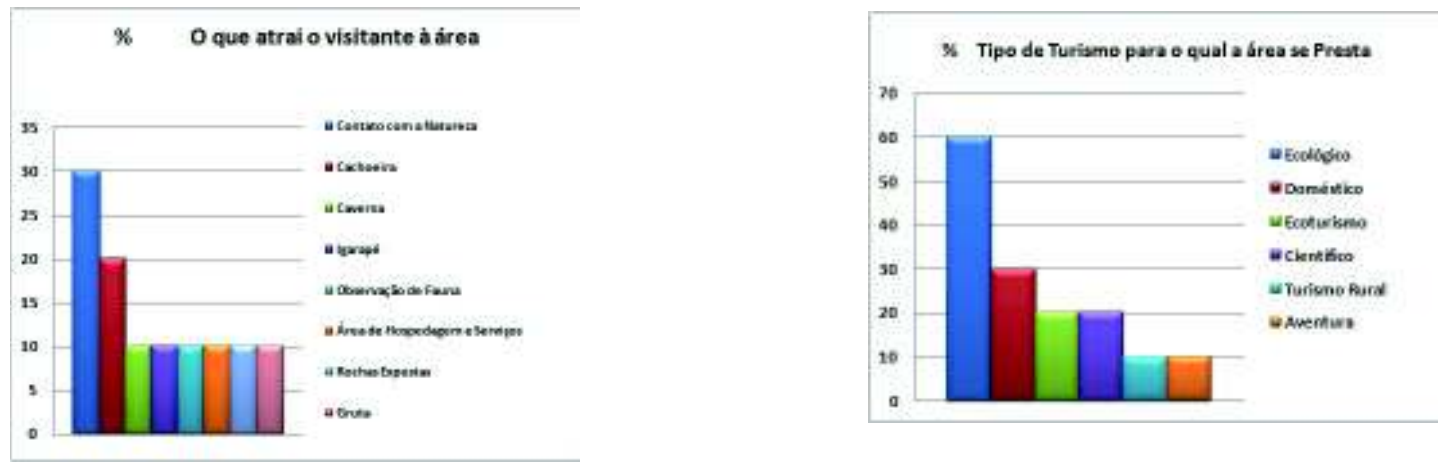

Figura 6 -Atratividade das áreas: a) O que atrai o visitante; e b) Tipo de turismo para o qual a área se presta.

Sobre o segmento de turismo (Figura 6 b) mais adequado para as áreas grande parte dos entrevitados citaram o turismo ecológico $(60 \%)$, que necessariamente não foca para a conservação de áreas e também não se estende prioritariamente a áreas sob alguma proteção restrita. O ecoturismo foi apontado por $20 \%$ dos gestores, tendo como premissas a compatibilidade entre o uso e conservação das áreas, apenas nesse caso, de forma teórica. Uma das modalidades citadas foi o turismo doméstico, na qual seus usuários visitam, prioritariamente, locais com infraestrutura adequadas para hospedagem e alimentação aos seus visitantes.

O turismo científico foi citado por $20 \%$ dos entrevistados, no entanto ele se presta a um público seletivo e que desenvolve atividades mais segmentadas. O turismo de aventura, assim como o turismo rural, obtiveram apenas $10 \%$ das citações, respectivamente, demonstrando que as áreas não possuem estrutura e pessoal qualificado para realização e monitoramento de atividades de lazer dessas modalidades.

Quanto a quantidade de visitantes por final de semana (Figura 7 a), grande parte dos atrativos recebem até 100 visitantes em média (50\%). Destaca-se que 10\% dos entrevitados, respectivamente, recebem de 300 a 400 visitantes em média, e que $20 \%$ recebem até 200 visitantes. As áreas com maior número de visitas são as que apresentam maior possibilidade de realização das atividades de banho e mergulho, 
além da diversidade de formas espeleológicas existentes. Apenas 10\% dos entrevitados informaram que na área não há visitação permanente.
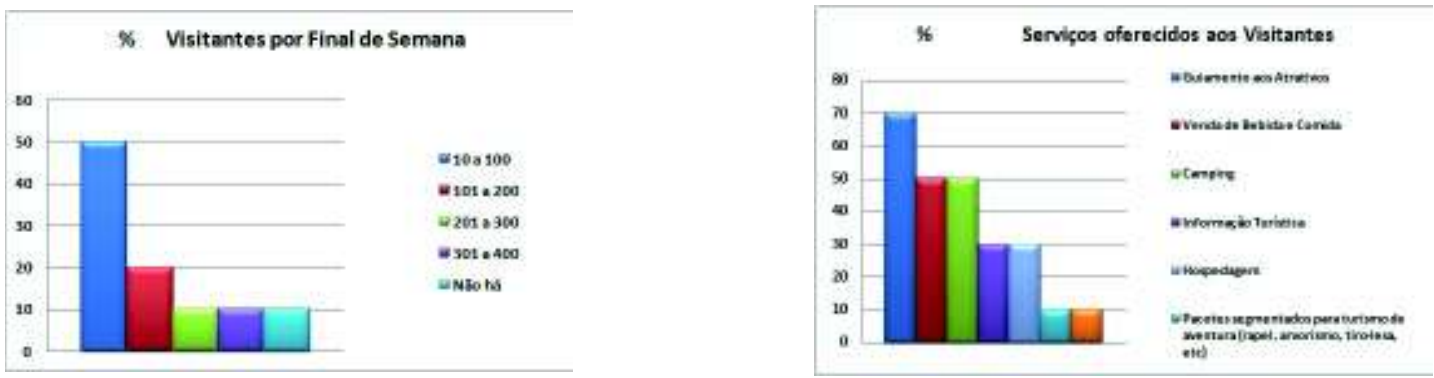

Figura 7 - Gestão dos visitantes: a) Quantidade de visitantes por final de semana; e b) Serviços oferecidos aos visitantes.

Sobre os serviços oferecidos aos vitantes (Figura 7 b), $70 \%$ dos entrevitados informaram que há guiamento aos atrativos das áreas. Além disso, 50\% dos gestores apontaram que há, respectivamente, venda de bedidas e comida, e destinação de áreas para camping/pernoite. Os serviços prioritários de informação turística e hospedagem obtiveram apenas $30 \%$ de citação. Observa-se, desta forma, a grande carência dos atrativos quanto a infraestrutura e organização. Apenas $10 \%$ dos entrevistados citaram a existência pacotes para atividades de aventura e que não há serviços, respectivamente.

c) Nível de Gestão e normas para uso público

Os atrativos estão divididos igualitariamente quanto ao perfil de gestão e regulamentação (Figura 8), desta forma, metade $(50 \%)$ tem acesso livre regulado, onde os visitantes acessam de forma geral, mas há regras mínimas para uso $(70 \%)$. E também onde o acesso é restrito regulado em que o uso e realizado somente com autorização do proprietário, que pode ou não obter lucro com a utilização da área, tendo grandes possibilidades de possuir normas de uso público (20\%). No entanto, $10 \%$ dos entrevistados citaram que os atrativos não possuem medidas de gestão básicas.
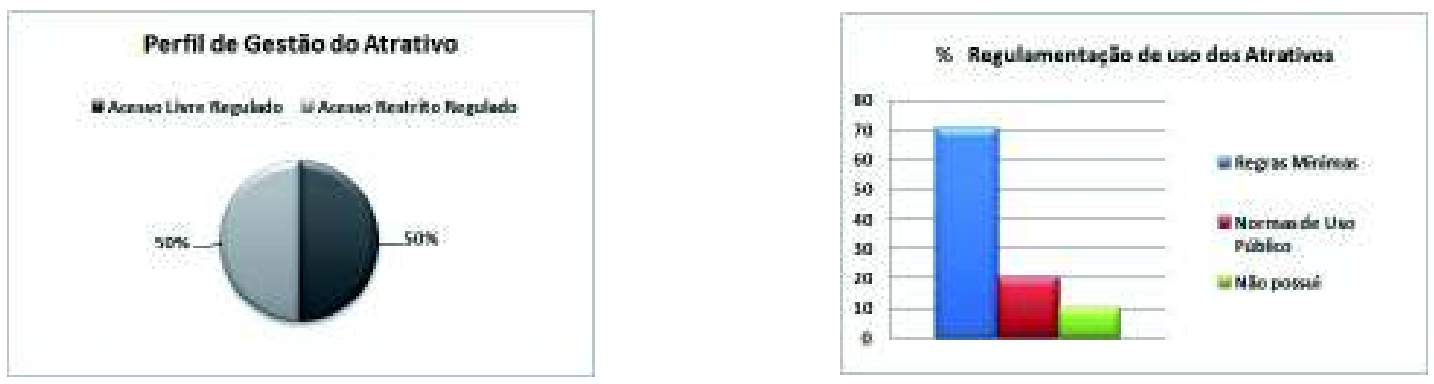

Figura 8 - Nível de gestão e normas de uso público: a) perfil de gestão; e b) regulamentação de uso dos atrativos. 
Observa-se, no entanto, a inexistência dos planos de capacidade de carga e de administração de visitantes. Segundo Wearing e Neil (2001), sem regulamentação adequada das atividades do setor privado e o manejo consistente da área de proteção, o desenvolvimento do ecoturismo pode causar impacto adverso sobre a base de recursos da qual depende. Porém uma prática turística viável precisa ser direcionada levando em conta os imperativos do mercado.

\section{d) Infraestrutura}

A maioria das áreas não possui infraestrutura adequada para atender a clientela, citado por $70 \%$ dos entrevistados (Figura 9 a). O que evidencia e comprova o grande déficit no gerenciamento adequado das áreas em função a inexistência de investimentos. No entanto, $20 \%$ dos entrevistados apontam que há infraestrutura básica sem descaracterizar as áreas. Cabe destacar, se a estrutura existente supre a demanda de serviços, solicitadas ou necessárias, à comodidade do visitante. Apenas $10 \%$ dos entrevistados informaram a existência de infraestrutura adequada a hospedagem e estadia do visitante. De forma paritária, metade das áreas não apresentam banheiros adaptados as condições ambientais (Figura 9 b), sendo prioritária a solução a esta situação.
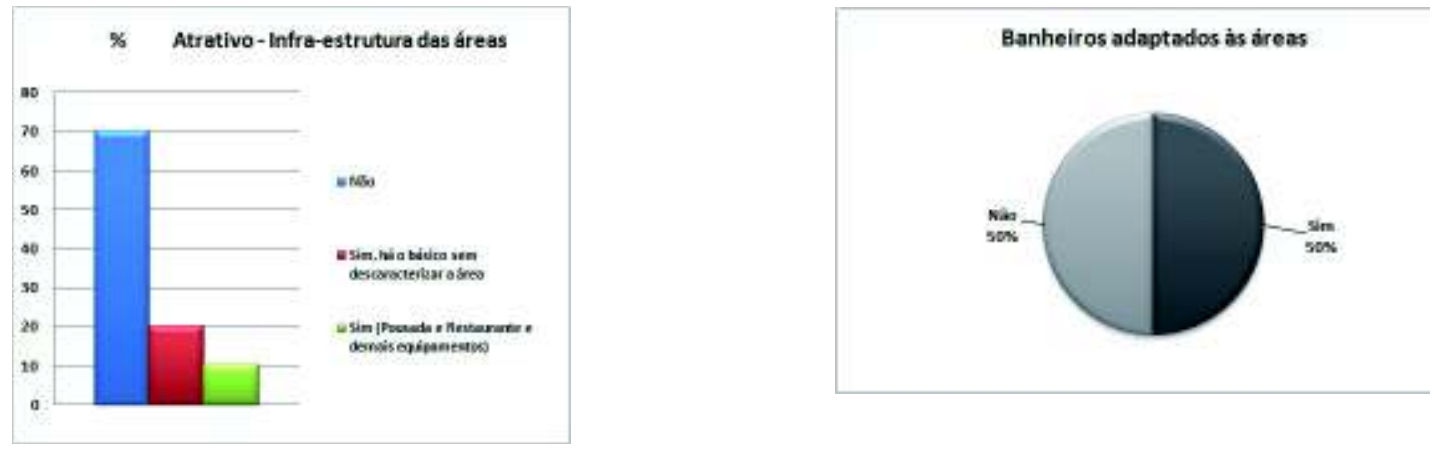

Figura 9 - Infraestrutura: a) Situação da infraestrutura; e b) banheiros adaptados às condições ambientais das áreas.

\section{e) Manutenção e Administração}

Na maioria das áreas estão empregados entre 01 a 10 pessoas, trabalhadoras diretas e indiretas em sua gestão e junto aos visitantes ( $80 \%$ ), enquanto em apenas $20 \%$ há até 20 pessoas (Figura $10 \mathrm{~b}$ ). Quando indagados sobre a capacitação dos trabalhadores (Figura 10 a), grande parte possui formação superior $(60 \%)$, nas áreas de administração, turismo e de ciências da natureza. Há também técnicos que trabalham como guias turísticos $(40 \%)$, técnicos em meio ambiente (30\%) e com capacitação em Hotelaria e Alimentação (20\%). No entanto, observou-se que $40 \%$ dos entrevistados informaram a existência de pessoas sem capacitação técnica para o turismo, que é um dos maiores problemas da região. Observase, por outro lado, o envolvimento de fiscais ambientais na gestão de áreas naturais para o turismo com $20 \%$ das citações. 

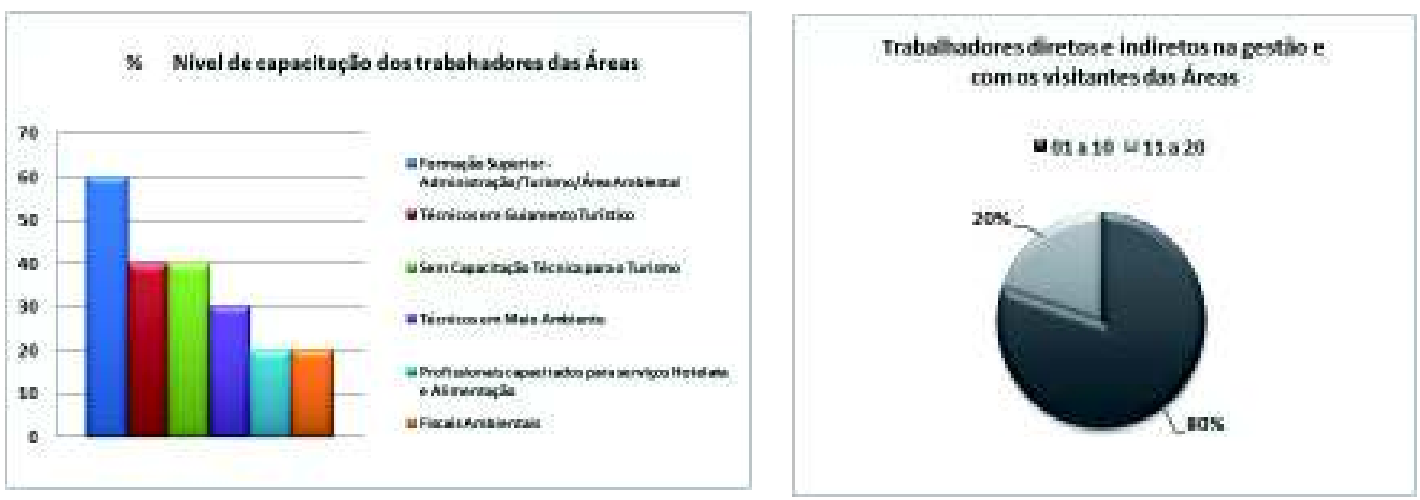

Figura 10 - Corpo profissional das áreas: a) Nível de capacitação dos trabalhadores; e b) Quantidade de trabalhadores empregados.

Sobre o gerenciamento dos resíduos sólidos produzidos pelos visitantes (Figura 11.), 80\% dos entrevistados informaram que há coleta pelos funcionários, e que são destinados ao coletor de público de lixo (40\%). Quando esse procedimento não é adotado, é realizada a queima dos resíduos (20\%), o que é prejudicial para a área e os visitantes, quanto aos resíduos resistentes ao fogo e a poluição visual da área. Apenas $10 \%$ dos entrevitados informaram que os visitantes cuidam de seus resíduos, chegando-se a intuir que os visitantes não possuem necessariamente cuidado com os rastros que podem provocar ou com a integridade ambiental das áreas.

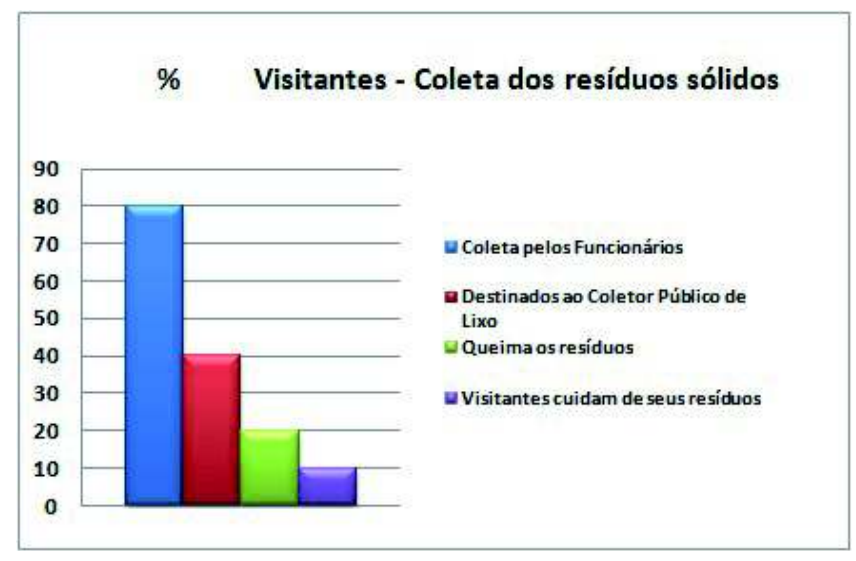

Figura 11. - Coleta e destino aos resíduos sólidos dos visitantes

Quando indagados sobre o que deveria melhorar nas áreas (Figura 12.), os entrevitados foram enfáticos em destacar a implantação de infraestrutura administrativa adequada (30\%), tanto ao atendimento eficaz dos visitantes como compatível a situação ambiental dos locais. Além da existência de trilhas mais adequadas $(10 \%)$ e condições para acessibilidade à deficientes fissicos $(20 \%)$. Enfatizaram também a pos- 
sibilidade de implementação de apoio financeiro (20\%) e da captação de mão-de-obra fixa e qualificada, que é um dos grandes problemas existentes na gestão das áreas. Outro aspecto citado foi a importância da realização de eventos nos atrativos, que é um grande fonte de arrecadação, no entanto, esse aspecto ressalta a ausência de uma politica consistente de divulgação das áreas.

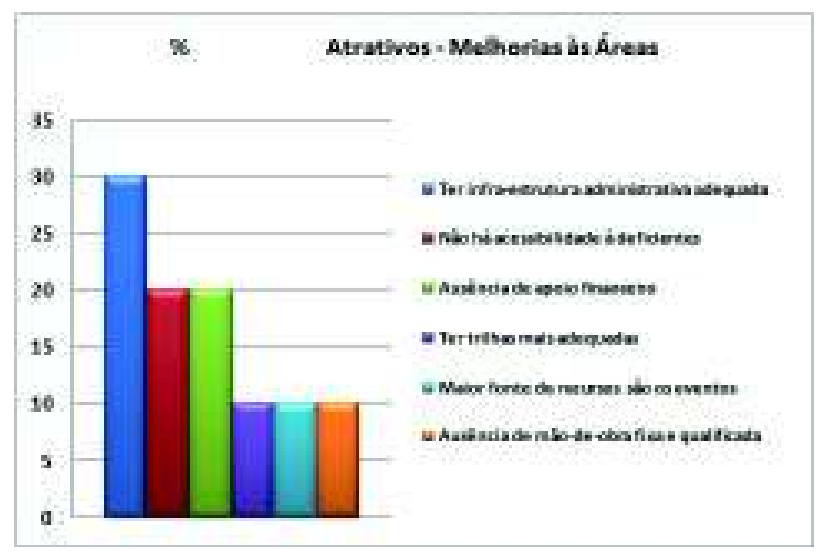

Figura 12 - Melhorias apropriadas às áreas.

Os entrevistados apontaram distintos valores para acesso e permanência das áreas vinculados aos serviços oferecidos (Figura 13 a). Sendo assim, há valores específicos para pernoite (Acampamento - R \$ $15,00)$ com $20 \%$. Para atividade de visita diurna os valores variam entre R $2,00(10 \%), \mathrm{R} \$ 5,00(20 \%)$ e R \$ 10,00 (10\%) por pessoa. Por grupo de até 12 pessoas é cobrado o valor de R $\$ 50,00(10 \%)$ e por veículo o valor de $\mathrm{R} \$ 10,00(10 \%)$. No entanto, cabe destacar que nos atrativos localizados em unidades de conservação municipais, $20 \%$ dos entrevistados enfatizaram a inexistência de orçamento público para gestão. Apenas $10 \%$ dos entrevistados informaram que é pago um valor simbólico, de acordo com os serviços solicitados pelos visitantes das áreas.
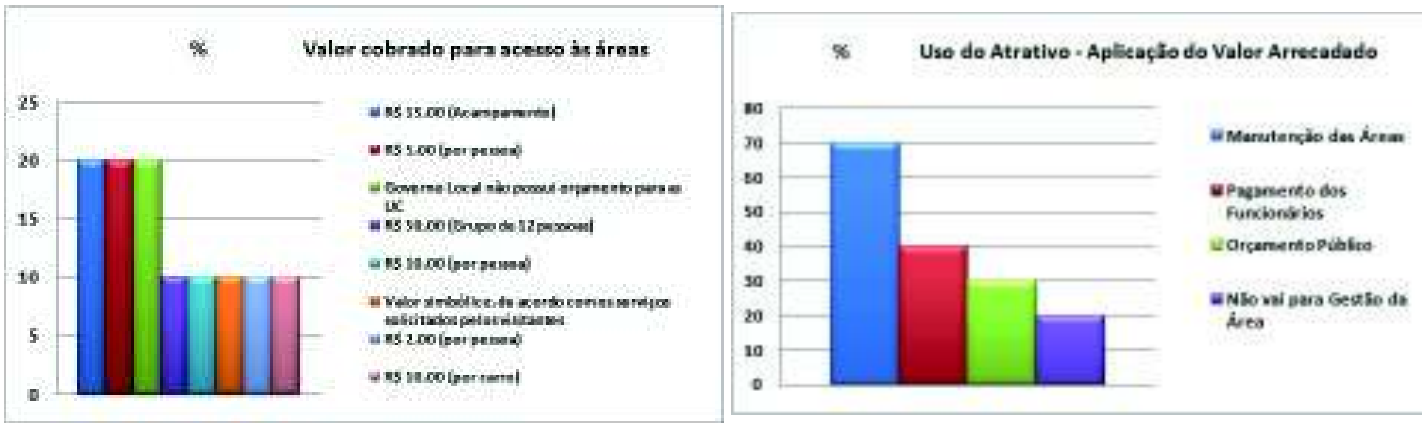

Figura 13 - Valor do acesso e permanência nas áreas: a) Valor pago; e b) Aplicação do valor arrecadado 
Sobre o investimento do valor arrecado oriundo da visitação (Figura 13 b), 70\% dos entrevistados ressaltaram a aplicação na manutenção das áreas. Seguida pelo pagamento de funcionários por $40 \%$. No entanto, $30 \%$ dos entrevistados informaram que recurso é do orçamento público. Destaca-se que $20 \%$ dos informantes responderam que o recurso não é aplicado na gestão da área, contribuindo, desta forma, diretamente com a renda familiar do proprietário do local. Esse fato nos remete a carência dessas áreas, e também seu uso ser a única fonte de renda dessas pessoas, diante a ausência de qualificação profissional para o mercado de trabalho.

f) Uso pretérito do atrativo

Quando indagados sobre as condições de uso e ocupação da terra na área onde está situado o atrativo (Figura 14), os entrevistados informaram que $70 \%$ eram cobertos por florestas. Destacaram que $40 \%$ pertenciam a propriedades privadas com exploração ilegal de madeira. Esse fato comprova que o uso turístico da área atualmente foi a segunda opção de grande parte dos proprietários, após o extermínio das espécies florestais de madeira nobre de sua propriedade. Citados por $10 \%$ dos informantes, respectivamente, enfatizam que as áreas eram cobertas por plantações agroflorestais e Fazenda de criação de gado, com pastagem. Esse último aspecto também remete que o uso das áreas para o turismo é uma segunda alternativa, haja vista a grande quantidade de pastagem abandonada na região da APA Caverna do Maroaga.

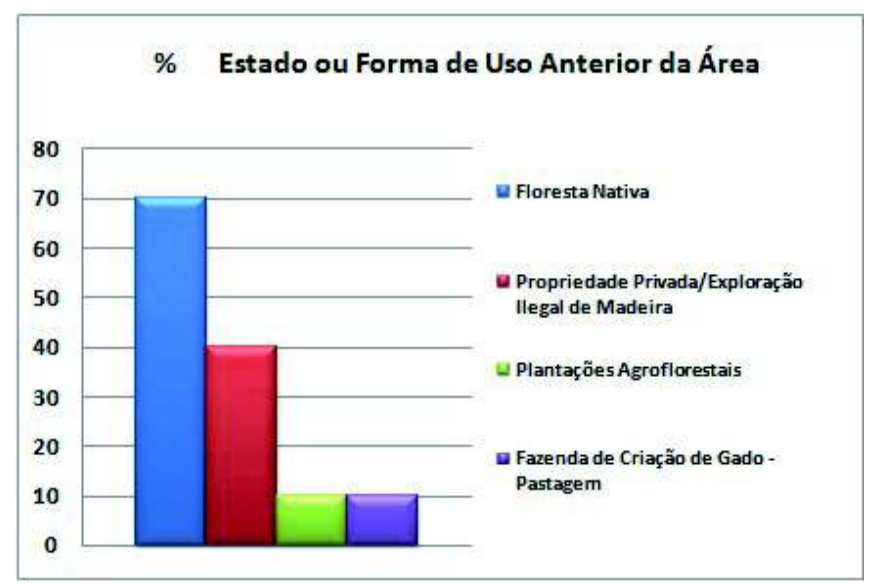

Figura 14 - Estado e forma de uso da área anterior ao uso turístico

\section{A situação de desenvolvimento dos atrativos naturais}

As considerações dos gestores sobre os pontos mais importantes para a melhoria do gerenciamento dos atrativos, observando suas possibilidades de sucesso e possíveis debilidades para solução imediata são discriminadas na planilha FOFA (Tabela 2).

A quantificação dos valores aos fatores destacados nas oportunidades e ameaças externas ao atrativo está discriminada na Matriz de Avaliação de Fatores Externos (Tabela 3.). A soma dos resultados da tabela de fatores internos é de 3.18, tendo grande perspectiva para aproveitar cinco oportunidades e reduzir oito ameaças externas identificadas. 
A quantificação dos valores aos fatores destacados nas oportunidades e ameaças internas ao atrativo é apresentado na Matriz de Avaliação de Fatores Internos (Tabela 4). A soma dos resultados da tabela de fatores internos é de 2.96. No entanto, é inferior ao resultado da matriz de fatores externos. Porém demonstra o grande desafio a ser enfrentado pelos gestores para aproveitar as seis oportunidades e reduzir cinco ameaças internas identificadas.

Na planilha FOFA observa-se que a maior preocupação dos gestores está na ausência de investimentos em capacitação e financiamento que possam auxiliar na administração e infraestrutura do atrativo. De certo, há o reconhecimento do grande potencial das áreas em atrair visitantes devido as suas formas singulares e únicas. No entanto, as ações de degradação dos ambientes é fator claro de desagregação de valor de uso das áreas (atualmente mal valorizadas), e que pode propiciar a perca de sua originalidade e perfil conservacionista. Um dos fatores principais está no avanço do desflorestamento e ocupações espontâneas no interior da APA Caverna do Maroaga, além do comprometimento da balneabilidade dos cursos d'água.

Um dos aspectos utilizados para inibição da degradação ambiental dos atrativos atualmente é o grande foco da atuação dos órgãos de governo na criação de reservas privadas na categoria Reserva Particular do Patrimônio Natural (RPPN). No entanto, para atender os dispositivos do Decreto $\mathrm{n}^{\circ} 5.746$, de 05 de abril de 2006, que regulamenta o Sistema Nacional de Unidades de Conservação da Natureza (SNUC), Lei $n^{\circ} 9.985$ de 18 de julho de 2000, quanto à criação de RPPN, o proprietário rural deve seguir procedimentos administrativos para solicitação da instituição da referida reserva privada, porém como já observado os atrativos naturais da APA Caverna do Maroaga, mesmo, os situados em RPPN, não possuem licenciamento ambiental como Balneários e similares pelo Instituto de Proteção Ambiental do Estado do Amazonas (IPAAM).

Desta forma, para o proprietário é mais cômodo continuar com o gerenciamento da área sem qualquer proteção oficial mais restritiva, a ter, ao buscar a criação de RPPN, que desembolsar recurso financeiro para contratação de consultoria técnica para georreferenciar toda a sua propriedade e também a área a ser transformada em reserva privada, assim como, a instituição de memorial descritivo e a elaboração de um diagnóstico sintético de relevância da área.

Outro aspecto que inviabiliza a constituição da reserva privada é a obrigatoriedade de certidão de matrícula e registro de imóveis, indicando a cadeia dominial válida e ininterrupta, trintenária ou desde sua origem (Brasil, 2006). Grande parte das áreas usadas para o turismo possuem em média cerca de 10 a 15 anos de uso, e a maioria foi adquirida por posse espontânea de terra. Os atrativos estão inseridos em lotes e/ou propriedades localizadas em um assentamento rural e em uma unidade de conservação, áreas que atendem o ordenamento da ocupação e aos fins de conservação/preservação da biodiversidade, porém obedecem a marcos legais diferenciados e estratégias de gestão distintas, sejam estas expressas nos planos de gestão/manejo ainda em elaboração. A instabilidade fundiária dos atrativos é o principal fator que inviabiliza a aquisição de empréstimos junto ao Banco da Amazônia (BASA) ou Agência de Fomento do Amazonas (AFEAM). 
Tabela 2 - Matriz FOFA

\begin{tabular}{|c|c|}
\hline FORÇAS & FRAQUEZAS \\
\hline $\begin{array}{l}\text { 1. Potencial turístico do atrativo; } \\
\text { 2. Cursos de Capacitação da AMAZONASTUR/ } \\
\text { SEBRAE e SENAC; } \\
\text { 3. Áreas em bom estado de conservação; } \\
\text { 4. Interesse e entusiasmo empreendedor; } \\
\text { 5. Freqüência assídua e vínculo de amizade com } \\
\text { os visitantes; } \\
\text { 6. Parceria com órgãos de governo municipal e } \\
\text { estadual; } \\
\text { 7. Tranqüilidade e segurança; } \\
\text { 8. Qualidade nos serviços; } \\
\text { 9. Apoio financeiro da Agência de Fomento do } \\
\text { Amazonas (AFEAM); } \\
\text { 10. Única fonte de renda para os proprietários; } \\
\text { 11. Diversidade de aves; } \\
\text { 12. Rodovia pavimentada; } \\
\text { 13. Boas condições de relevo; } \\
\text { 14. Existência de água potável; } \\
\text { 15. Título definitivo para o empreendedor. }\end{array}$ & $\begin{array}{l}\text { 1. Ausência de apoio financeiro; } \\
\text { 2. Vulnerabilidade ambiental do local; } \\
\text { 3. Ausência de apoio do Governo Estadual na criação de UC mais } \\
\text { restritivas que a APA Caverna do Maroaga; } \\
\text { 4. Inoperância do CEUC/SDS na gestão da APA Caverna do } \\
\text { Maroaga; } \\
\text { 5. Ausência de autonomia municipal na gestão ambiental; } \\
\text { 6. Ausência de controle do fluxo de visitantes; } \\
\text { 7. Ausência de estudos de Capacidade de Carga/Suporte e com- } \\
\text { plementares; } \\
\text { 8. Ausência de infraestrutura adequada às condições da área; } \\
\text { 9. Ausência de solução ao ordenamento fundiário dos atrativos; } \\
\text { 10. Turistas inconscientes; } \\
\text { 11. Destruição das APP e dejetos ao longo do Igarapé a montante } \\
\text { dos atrativos; } \\
\text { 12. Escassez de mão-de-obra local; } \\
\text { 13. Ausência do apoio do poder público municipal na divulgação } \\
\text { das áreas; } \\
\text { 14. Ausência de profissionais capacitados; } \\
\text { 15. Falta de recursos públicos municipais para gestão das UC; } \\
\text { 16. Inexistência de apoio governamental na capacitação técnica; } \\
\text { 17. Endividamento no envolvimento com financiamento público; } \\
\text { 18. Ausência de recursos próprios para fazer melhorias em infra- } \\
\text { estrutura. }\end{array}$ \\
\hline OPORTUNIDADES & AMEAÇAS \\
\hline $\begin{array}{l}\text { 1. Potencial turístico do atrativo; } \\
\text { 2. Perspectiva de apoio à capacitação profissional } \\
\text { técnica em turismo; } \\
\text { 3. } \quad \text { Perspectiva a apoio financeiro com acesso a } \\
\text { empréstimos; } \\
\text { 4. Atenção do governo municipal; } \\
\text { 5. Obtenção do título definitivo das propriedades; } \\
\text { 6. Melhorias na infraestrutura da área; } \\
\text { 7. Estímulo ao turismo com o Jogo da Copa Mundial } \\
\text { de Futebol em Manaus; } \\
\text { 8. Divulgação da área com apoio do Governamental; } \\
\text { 9. Viabilização de ações de educação ambiental aos } \\
\text { usuários; } \\
\text { 10. Visitação freqüente - dirigida e seletiva; } \\
\text { 11. } \quad \text { Fácil acesso. }\end{array}$ & $\begin{array}{l}\text { 1. Expansão urbana de Presidente Figueiredo (ocupações espon- } \\
\text { tâneas no entorno do atrativo); } \\
\text { 2. Degradação dos atrativos pela ausência de gerenciamento } \\
\text { adequado; } \\
\text { 3. Visitação não autorizada; } \\
\text { 4. Desflorestamentos - extração ilegal de madeira; } \\
\text { 5. Ausência de planejamento da visitação e Planos de Capacidade } \\
\text { de Carga; } \\
\text { 6. Ausência de respaldo concreto quanto à criação de UC mais } \\
\text { restritivas que a APA Caverna do Maroaga; } \\
\text { 7. Ausência de regularização fundiária; } \\
\text { 8. Agências turísticas não cumprem normas municipais; } \\
\text { 9. Ausência de infraestrutura e sinalização turística nos atrativos; } \\
\text { 10. Desflorestamento das APP do Igarapé a montante dos atrativos; } \\
\text { 11. Ausência de capacitação técnica em turismo e empreendedo- } \\
\text { rismo; } \\
\text { 12. Ausência de conscientização dos usuários; } \\
\text { 13. Pressão sobre a fauna e flora. }\end{array}$ \\
\hline
\end{tabular}

No entanto, a execução dos procedimentos para instituição da reserva privada já estaria ligado aos procedimentos de licenciamento ambiental para a atividade que o interessado executa na área, bem como, ao diagnóstico ambiental das condições de uso público das áreas que atualmente não possuem normas 
claras de gestão e manejo, estando em condições de continua degradação dos ambientes pelos visitantes e demais usuários. O lado positivo da criação de RPPN e do Licenciamento ambiental (averbação de Reserva Legal e delimitação de APP privadas) é o desconto dessas áreas no pagamento do Imposto Territorial Rural (ITR).

Tabela 3 - Matriz External Factor Evaluation - EFE

\begin{tabular}{|c|c|c|c|c|}
\hline \multicolumn{2}{|r|}{ Fatores Críticos de Sucesso } & Peso & Desempenho & Resultado \\
\hline \multirow{5}{*}{$\begin{array}{l}\text { Oportunidades } \\
\text { (Pontos Fortes) }\end{array}$} & $\begin{array}{l}\text { Perspectiva de apoio à capacitação profis- } \\
\text { sional técnica em turismo }\end{array}$ & 0.09 & 4.0 & 0.36 \\
\hline & Estímulo ao turismo com a Copa do Mundo & 0.08 & 2.0 & 0.16 \\
\hline & $\begin{array}{l}\text { Perspectiva a apoio financeiro com acesso } \\
\text { a empréstimos }\end{array}$ & 0.08 & 3.0 & 0.24 \\
\hline & $\begin{array}{l}\text { Divulgação da área com apoio do Gover- } \\
\text { namental }\end{array}$ & 0.06 & 1.0 & 0.06 \\
\hline & Atenção do governo municipal & 0.06 & 1.0 & 0.06 \\
\hline \multirow{8}{*}{$\begin{array}{c}\text { Ameaças } \\
\text { (Pontos Fracos) }\end{array}$} & $\begin{array}{l}\text { Expansão urbana de Presidente Figuei- } \\
\text { redo (ocupações espontâneas no entorno do } \\
\text { atrativo) }\end{array}$ & 0.09 & 4.0 & 0.36 \\
\hline & $\begin{array}{l}\text { Ausência de respaldo concreto quanto } \\
\text { à criação de UC mais restritivas que a APA } \\
\text { Caverna do Maroaga }\end{array}$ & 0.09 & 4.0 & 0.36 \\
\hline & $\begin{array}{l}\text { Desflorestamento das APP do Igarapé a } \\
\text { montante dos atrativos }\end{array}$ & 0.09 & 4.0 & 0.36 \\
\hline & $\begin{array}{l}\text { Ausência de capacitação técnica em turis- } \\
\text { mo e empreendedorismo }\end{array}$ & 0.09 & 4.0 & 0.36 \\
\hline & $\begin{array}{l}\text { Desflorestamentos - extração ilegal de } \\
\text { madeira }\end{array}$ & 0.09 & 4.0 & 0.36 \\
\hline & Ausência de regularização fundiária & 0.09 & 4.0 & 0.36 \\
\hline & $\begin{array}{l}\text { Agências turísticas não cumprem normas } \\
\text { municipais }\end{array}$ & 0.05 & 2.0 & 0.10 \\
\hline & Ausência de conscientização dos usuários & 0.04 & 1.0 & 0.04 \\
\hline & Somatório & 1.00 & & 3.18 \\
\hline
\end{tabular}

Geralmente, as propriedades não possuem a averbação de reserva legal e nem delimitação de APP. Esses procedimentos somente são requeridos mediantes a busca pelos proprietários de licenciamento ambiental para algum tipo de atividade produtiva para a qual seu funcionamento venha obrigatoriamente ser vinculado a expedição de licença prévia, licença de instalação ou licença de operação pelo órgão ambiental.

Esse fato ligado a ausência de monitoramento ambiental nos empreendimentos licenciados e a essas tipologias de áreas protegidas na Amazônia e a inexistência de ações constantes para fiscalização ambiental, haja vista a grande demanda e a dificuldade de implementação de infraestrutura, logística e de pessoal nos órgãos ambientais competentes, colaboram para a vulnerabilidade ambiental de atrativos turísticos naturais. 
Tabela 4 - Matriz Internal Factor Evaluation - IFI

\begin{tabular}{|c|c|c|c|c|}
\hline \multicolumn{2}{|r|}{ Fatores Críticos de Sucesso } & Peso & Desempenho & Resultado \\
\hline \multirow{6}{*}{$\begin{array}{c}\text { Oportunidades } \\
\text { (Pontos } \\
\text { Fortes) }\end{array}$} & Potencial turístico do atrativo & 0.10 & 3.0 & 0.30 \\
\hline & Obtenção do título definitivo das propriedades & 0.10 & 4.0 & 0.40 \\
\hline & Visitação freqüente - dirigida e seletiva & 0.09 & 3.0 & 0.27 \\
\hline & Fácil acesso & 0.09 & 2.0 & 0.18 \\
\hline & Melhorias na infraestrutura da área & 0.09 & 1.0 & 0.09 \\
\hline & $\begin{array}{l}\text { Viabilização de ações de educação ambiental } \\
\text { aos usuários }\end{array}$ & 0.08 & 1.0 & 0.08 \\
\hline \multirow{5}{*}{$\begin{array}{c}\text { Ameaças } \\
\text { (Pontos } \\
\text { Fracos) }\end{array}$} & $\begin{array}{l}\text { Degradação dos atrativos pela ausência de } \\
\text { gerenciamento adequado }\end{array}$ & 0.10 & 4.0 & 0.40 \\
\hline & $\begin{array}{l}\text { Ausência de planejamento da visitação e Planos } \\
\text { de Capacidade de Carga }\end{array}$ & 0.09 & 4.0 & 0.36 \\
\hline & $\begin{array}{l}\text { Ausência de infraestrutura e sinalização turís- } \\
\text { tica nos atrativos }\end{array}$ & 0.09 & 4.0 & 0.36 \\
\hline & Visitação não autorizada & 0.09 & 4.0 & 0.36 \\
\hline & Pressão sobre a fauna e flora & 0.08 & 2.0 & 0.16 \\
\hline \multicolumn{2}{|r|}{ Somatório } & 1.00 & & 2.96 \\
\hline
\end{tabular}

As principais estratégias para a melhoria das condições de gerenciamento dos atrativos da APA Caverna do Maroaga (Tabela 5) estão vinculadas a priori a fase atual de elaboração do seu plano de gestão/ manejo, por meio de consultoria contratada, e ao interesse que possivelmente possa ser despertado pela iniciativa privada ou Organizações Não-Governamentais (ONG’s) em atuar na coordenação de ações pontuais na formulação e implantação de medidas de gestão, haja vista a demanda de ações existentes para as quais o órgão gestor não tem suprido. Diante disso, sugere-se as seguintes estratégias para solução dos passivos ambientais na gestão das áreas naturais.

\section{CONSIDERAÇÕES FINAIS}

O estado atual de gerenciamento incipiente das áreas naturais da APA Caverna do Maroaga são exemplos de como se encontram a grande parte dos atrativos naturais atualmente em uso pela atividade turística na Amazônia, desprovidos de licenciamento ambiental para o desenvolvimento da atividade e de monitoramento ambiental. De forma geral, observa-se que a carência na formação profissional dos proprietários e demais indivíduos envolvidos na administração dos atrativos, condiciona a minimização do tempo de uso dos locais e a degradação de sua qualidade paisagística.

No entanto, cabe destacar a inexistência de profissionais voltados a formular, discutir e implantar mecanismos mais eficazes para o desenvolvimento do turismo e sua compatibilização com a conservação das áreas, enfatizando-se as pesquisas voltadas a dotar essas áreas com infraestrutura adequada e normas e diretrizes específicas para visitação com termos de condutas claros. Dessa forma, podem-se destacar os seguintes pontos: 
Tabela 5 - Estratégias gerais para as áreas naturais da APA Caverna do Maroaga

\begin{tabular}{|c|c|c|c|}
\hline $\mathbf{N}^{0}$ & Pressões & Fontes & Estratégias \\
\hline 1 & $\begin{array}{l}\text { Alteração da } \\
\text { estrutura da ve- } \\
\text { getação e com- } \\
\text { prometimento } \\
\text { da balneabili- } \\
\text { dade dos cursos } \\
\text { d'água }\end{array}$ & $\begin{array}{l}\text { 1. Práticas incompatíveis } \\
\text { de turismo (pisoteamento e } \\
\text { desflorestamento do entorno } \\
\text { dos cursos d'água); } \\
\text { 2. Desflorestamento ilegal } \\
\text { nas Áreas de Preservação } \\
\text { Permanente (APP) a mon- } \\
\text { tante dos atrativos; } \\
\text { 3. Expansão urbana de Pre- } \\
\text { sidente Figueiredo, com } \\
\text { ocupações espontâneas no } \\
\text { entorno dos atrativos. }\end{array}$ & $\begin{array}{l}\text { 1. Monitoramento dos impactos da visitação; } \\
\text { 2. Zoneamento das áreas de uso; } \\
\text { 3. Educação e diretrizes de conduta aos visitantes e proprietários; } \\
\text { 4. Licenciamento ambiental e monitoramento dos empreendi- } \\
\text { mentos; } \\
\text { 5. Fiscalização ambiental às práticas de desmatamento ilegal e } \\
\text { ocupações espontâneas na região; } \\
\text { 6. Elaboração de estudos sobre a balneabilidade dos atrativos. }\end{array}$ \\
\hline 2 & $\begin{array}{l}\text { Contaminação } \\
\text { (poluição orgâ- } \\
\text { nica e dejetos } \\
\text { sólidos) }\end{array}$ & $\begin{array}{l}\text { 1. Ausência de infraestru- } \\
\text { tura adequada para estadia } \\
\text { e alimentação dos visitantes } \\
\text { e de tratamento de águas- } \\
\text { servidas; } \\
\text { 2. Inexistência de banhei- } \\
\text { ros adaptados a área; } \\
\text { 3. Ausência de conscienti- } \\
\text { zação dos usuários; } \\
\text { 4. Visitação não autori- } \\
\text { zada. }\end{array}$ & $\begin{array}{l}\text { 1. Diretrizes de infraestrutura básica e adaptada as condições } \\
\text { ambientais da área; } \\
\text { 2. Licenciamento ambiental dos empreendimentos; } \\
\text { 3. Instituição de códigos de conduta e multas as irregularidades } \\
\text { práticas pelos visitantes; } \\
\text { 4. Monitoramento da visitação. }\end{array}$ \\
\hline 3 & $\begin{array}{l}\text { Perda da origina- } \\
\text { lidade dos atrati- } \\
\text { vos (pichações, } \\
\text { fogueiras, etc) }\end{array}$ & $\begin{array}{l}\text { 1. Ausência de capacitação } \\
\text { técnica em turismo e empre- } \\
\text { endedorismo; } \\
\text { 2. Ausência de infraestru- } \\
\text { tura e sinalização turística } \\
\text { nos atrativos. } \\
\text { 3. Inexistência de plane- } \\
\text { jamento e monitoramento } \\
\text { da visitação e Planos de } \\
\text { Capacidade de Carga; } \\
\text { 4. Ausência de regulariza- } \\
\text { ção fundiária. }\end{array}$ & $\begin{array}{l}\text { 1. Elaboração de um Programa de Capacitação em Gestão do } \\
\text { Turismo em Áreas Naturais; } \\
\text { 2. Articulação junto aos órgãos fundiários para regularização das } \\
\text { áreas que não possuem titularidade da terra; } \\
\text { 3. Criação de um programa específico de licenciamento ambiental } \\
\text { de áreas naturais com aspectos espeleológicos e geomorfológicos; } \\
\text { 4. Articulação junto ao } \\
\text { 5. órgãos de fomento para busca de financiamento aos empre- } \\
\text { endimentos; } \\
\text { 6. Criação de um Grupo de Trabalho Específico para a formu- } \\
\text { lação e implantação de diretrizes de uso público adequadas as } \\
\text { áreas naturais; } \\
\text { 7. Busca de profissionais e articulação junto a órgãos de capa- } \\
\text { citação profissional para formação de pessoal para voltados a } \\
\text { administração da visitação; } \\
\text { 8. Elaboração de projetos arquitetônicos para as áreas, de acordo } \\
\text { com seu zoneamento; } \\
\text { 9. Formulação e implantação dos Planos de Gestão de Visitação/ } \\
\text { Ecoturismo. }\end{array}$ \\
\hline
\end{tabular}




\begin{tabular}{|c|c|c|c|}
\hline 4 & $\begin{array}{l}\text { Pressão sobre } \\
\text { a fauna, flora e } \\
\text { recursos hídricos }\end{array}$ & $\begin{array}{l}\text { 1. Ausência de respaldo } \\
\text { concreto quanto à criação } \\
\text { de UC mais restritivas que } \\
\text { a APA Caverna do Maroaga; } \\
\text { 2. Degradação dos atrati- } \\
\text { vos pela ausência de geren- } \\
\text { ciamento adequado. }\end{array}$ & $\begin{array}{l}\text { 1. Elaboração e implantação dos programas de gestão do Plano } \\
\text { de Manejo/Gestão da APA Caverna do Maroaga; } \\
\text { 2. O zoneamento deve destacar a seleção de áreas para criação } \\
\text { de UC públicas ou privadas mais restritivas que a categoria APA; } \\
\text { 3. Avaliação das áreas para criação de UC e a definição de qual } \\
\text { nível administrativo de governo irá efetuar a instituição; } \\
\text { 4. Criação de Grupo de Trabalho para Elaboração de Estudos de } \\
\text { Capacidade de Carga e Gestão da Visitação a todos os atrativos } \\
\text { da APA; } \\
\text { 5. Instituição de um Programa de criação e monitoramento de } \\
\text { Reservas Privadas, que englobe os três níveis administrativos } \\
\text { de governo; }\end{array}$ \\
\hline
\end{tabular}

1. Melhorias no gerenciamento das áreas naturais

A adoção de um amplo programa de uso público para essa unidade deve obrigatoriamente oferecer condições aos atuais proprietários de áreas naturais se inserirem em todas as fases de discussões e planejamento. Essa política deve ter três pilares básicos de atuação: a) a regulamentação das atividades de turismo nas áreas naturais, estabelecendo diretrizes e normas de condutas sujeitas a penalidades; b) a infraestruturação das áreas de acordo com suas condições biofísicas, provendo a adequação e estudos de viabilidade paisagística dos equipamentos ao ambiente, placas de localização, placas de sinalização interna, entre outros; e c) capacitação profissional em manejo de áreas naturais para o turismo.

Os gestores da APA Caverna do Maroaga possuem consciência do seu papel como patrocinadores do uso irregular dessas áreas. No entanto, o isolamento técnico dos órgãos de governo das três esferas administrativas e de distintos setores, aliada a morosidade burocrática, para a regularização da atividade ou mesmo para o credenciamento do título da propriedade, ocasiona o desinteresse e a reclusão dos proprietários a atuar sem capacitação e sem controle do uso da única atividade que lhe proporciona renda.

\section{Elaboração de estudos de viabilidade da oferta/demanda turística para áreas}

A ausência de planejamento e administração adequada para o turismo na unidade de conservação deixa visível a inércia governamental quanto ao atendimento às necessidades básicas de infraestrutura e gestão apropriada às condições ambientais dos locais. Principalmente, a disponibilização de placas de localização, roteirização dos atrativos, melhoria nas condições de trafegabilidade de estradas e ramais, entre outros. Soma-se a completa ausência de desenvolvimento das áreas como destinos turísticos, com seus recursos e produtos definidos e estruturados (principal, periféricos e complementares), o que influencia na durabilidade de sua sustentabilidade e, por conseguinte no seu ciclo de vida. Esse aspecto também remete a ausência de uma política de divulgação dos atrativos e de elaboração de planos de negócio.

\section{Pagamento por serviços ambientais prestados pelas áreas naturais}

Assim, como no uso da imagem, categoria APA e as reversas privadas também são excluídas do aproveitamento econômico de serviços ambientais desenvolvidos pelas áreas naturais. No entanto, esse fato não impede o desenvolvimento de mecanismos para incentivo a proteção de áreas naturais inseridas em 
propriedades privadas, a fim de inibir o avanço do desflorestamento, favorecer a recuperação de áreas degradadas, evitar a degradação dos recursos naturais e valorizar e ordenar o uso dos atrativos naturais e/ou culturais.

Um dos exemplos a serem seguidos é o Projeto-piloto de pagamento por serviços ambientais para a conservação florestal - ponto focal: município de Apuí. Esse projeto é desenvolvido nas áreas rurais de Apuí, onde se localiza o Mosaico de Unidades de Conservação Estaduais do Sul do Amazonas. Projeto este que possui dois pilares de atuação: um voltado ao aproveitamento do potencial turístico da região (Projeto de Desenvolvimento do Ecoturismo) e outro é voltado à implantação de um projeto de Redução de Emissões por Desmatamento e Degradação Florestal (REDD).

Outra iniciativa é o projeto "Apuí mais Verde" desenvolvido por órgão locais em parceria com uma ONG, tendo o objetivo de recuperar, por reflorestamento, áreas degradadas, reservas legais e de áreas de preservação permanente (APP), envolvendo agricultores e pecuaristas, além de promover o sequestro de carbono. Será efetuado no âmbito desse projeto, o pagamento anual de $\mathrm{R} \$ 80,00$ por hectare, por um período de 25 anos, aos proprietários que se cadastrarem no referido programa. Essas iniciativas podem orientar o desenvolvimento de novas alternativas e perspectivas de atuação para o gerenciamento ambiental de áreas naturais na APA Caverna do Maroaga.

\section{Estudos de Capacidade de Carga e planejamento e administração da visitação turística}

Em um parque devidamente implementado há todas as condições favoráveis para se ter um controle maior sobre o fluxo da visitação e poder contabilizá-lo, mas como esse procedimento será eficaz em uma APA, onde predomina as áreas privadas e o direito de propriedade. A alternativa é envolver e convencer os proprietários a colaborarem ou imporem sansões por meio da reedição da Instrução Normativa que regulamente o uso público dos atrativos naturais e estabeleça limites para realização de atividades potencialmente poluidoras, bem como, o registro do número de visitantes. A formulação de programas que visam ordenamento do uso turístico é essencial, principalmente a partir da elaboração de estudo de capacidade de carga/suporte e ferramentas para administração dos visitantes. Atualmente, a regulamentação e monitoramento das atividades turísticas na APA Caverna do Maroaga, apesar de sua vocação, são praticamente inexistentes, bem como, a realização de estudos que procurem averiguar a percepção e preferências dos usuários de áreas naturais.

Mesmo a criação de Reservas Particulares do Patrimônio Natural (RPPN) e parques municipais públicos sobrepostos a APA não são eficazes para proteção efetiva e ordenamento e regulamentação do uso público nessas áreas. Ressalta-se que a criação de unidades de conservação públicas ou privadas sobrepostas a essa categoria de UC é encarada como o principal leque de oportunidades que garante a concretização dos objetivos de instituição de APA. E esse discurso está presente no âmago de seus postulados de formulação na proposta de conservar ecossitemas relevantes em domínios da propriedade privada.

A grande possibilidade de orientar o desenvolvimento das atividades de turismo de forma sustentável está na possibilidade de destacar prioridades e apoios para o desenvolvimento de medidas de controle ambiental, que promovam o licenciamento, credenciamento e fomento das atividades. Além da obtenção de condições favoráveis para constituição de áreas com potencial turístico físico e gerencial que se consolidem em destinos. 


\section{REFERÊNCIAS BIBLIOGRÁFICAS}

ABRIC, J-C. A abordagem estrutural das representações sociais. In: MOREIRA, Antonia Silva Paredes; OLIVEIRA, Denize Cristina de (Org.). Estudos interdisciplinares de representação social. $2^{\mathrm{a}}$. Ed. Goiânia: AB, 2000. p 27-38.

AMAZONAS, Governo do Estado. Coletânea de Unidades de Conservação Federais e Estaduais: leis, decretos e portarias. Manaus: Governo do Estado do Amazonas - Secretaria de Estado de Meio Ambiente e Desenvolvimento Sustentável, 2009.

AZEVEDO, M. C. \& COSTA, H. G. Métodos para avaliação da postura estratégica. Cadernos de Pesquisa em Administração. V. 08. № 02, São Paulo: abril/junho de 2001. In: www.nossocontador.com/Artigos/45.pdf. Acesso: 02/10/2009. p 01-18.

BARDIN, L. Análise de Conteúdo. Lisboa-Portugal: Edições 70 Ltda, 1977. 230p.

BENSUSAN, N. Conservação da Biodiversidade em Áreas Protegidas. Rio de Janeiro: Editora da FGV, 2006. 176p.

BOO, E. O planejamento ecoturístico para áreas protegidas. In: LINDBERG, Kreg e HAWKINS, Donald E. (editores). Ecoturismo: um guia para planejamento e gestão. São Paulo: Editora SENAC São Paulo, 1995. p 31-57.

BRASIL. Decreto no 5.746, de 05 de abril de 2006 - regulamenta o art. 21 (instituição de Reserva Particular do Patrimônio Natural - RPPN) da Lei n ${ }^{\circ}$ 9.985, de 18 de julho de 2006, que dispõe sobre o Sistema Nacional de Unidades de Conservação da Natureza. Casa Civil. Presidência da República. Brasília, 2006.

BRASIL. Ministério do Turismo. Marcos Conceituais sobre Turismo. Secretaria Nacional de Políticas de Turismo, Departamento de Estruturação, Articulação e Ordenamento Turístico, Coordenação Geral de Segmentação. - Brasília: Ministério do Turismo, 2008 a. In: http://www.turismo.gov.br/export/sites/default/turismo/o_ministerio/publicacoes/ downloads_publicacoes/Marcos_Conceituais.pdf

BRASIL. Sistema Nacional de Unidades de Conservação da Natureza: Lei 9.985 de 18 de julho de 2000; Decreto $n^{\circ}$. 4.340, de 22 de agosto de 2002. 5a . Ed. Aum. Brasília: MMA/SBF, 2004.

CABRAL, Nájila Rejanne Alencar Julião e SOUZA, Marcelo Pereira de. Área de Proteção Ambiental: Planejamento e gestão de paisagens protegidas. $2^{\mathrm{a}}$ ed. São Carlos: RIMA, 2005.

CEBALLOS-LASCURÁIN, H. O ecoturismo com um fenômeno mundial. In: LINDBERG, K. \& HAWKINS, D. E. (editores). Ecoturismo: um guia para planejamento e gestão. São Paulo: Editora SENAC São Paulo, 1995. p 23-29.

DRUMM, A. \& MOORE, A. Introdução ao planejamento do ecoturismo. Desenvolvimento do Ecoturismo: um manual para profissionais de conservação. Volume 1. Virgínia: The Nature Conservancy, 2002. p 001-100.

DRUMOND, M. A. Participação comunitária no manejo de unidades de conservação: manual de técnicas e ferramentas. Belo Horizonte: Instituto Terras Brasilis de Desenvolvimento Sócio-Ambiental, 2002. 81p. www. terrabrasilis.org.br/ing/publicacoes/manual.pdf. Acesso: 02/03/2009.

FIDALGO, E.C.C. 2003. Critérios para a análise de métodos e indicadores ambientais usados na etapa de diagnóstico de planejamentos ambientais. Tese de Doutorado, Faculdade de Engenharia Agrícola, UNICAMP, Campinas, SP, 239p.

GADELHA, Eloísa Mendonça e ALECRIM, José Duarte. Turismo: impactos nos aspectos geomorfológicos da Área de Proteção Ambiental Presidente Figueiredo Caverna do Maroaga/ AM. Caderno de Turismo Virtual. ISSN: 1677-6976. Vol. 6, N 2, 2006. In:. http://www.eco-subterraneo.com.br/index.php?option=com_docman\&task=doc_ download\&gid=268. Acesso em: 09/01/2009.

GRESSLER, L. A. Introdução à pesquisa: projetos e relatórios. 2a ed. São Paulo: Loyola, 2004. 295p. 
LOBO, Heros Augusto Santos. Ecoturismo e percepção de impactos socioambientais sob a ótica dos turistas no Parque Estadual Turístico do Alto Ribeira - PETAR. Pesquisas em Turismo e Paisagens Cársticas, 1(1). Campinas: SeTur/SBE, 2008. In: http://www.sbe.com.br/ptpc/ptpc_v1_n1_067-076.pdf. Acesso em: 01/12/2009.

MARANGONI, A. M. M. C. Questionários e entrevistas: algumas considerações. In: Venturi, Luis Antonio Bittar. Praticando a geografia: técnicas de campo e laboratório. São Paulo: Oficina de Texto, 2005.

MARCONI, M. A. Técnica de pesquisa: planejamento execução de pesquisas, amostragens e técnicas de pesquisas, elaboração, análise e interpretação de dados. $5^{\mathrm{a}}$ Ed. São Paulo: Altas, 2002. 282p.

MINAYO, M. C. S. O conceito de Representações Sociais dentro da sociologia clássica. In: GUARESCHI, P. A.; JOVCHELOVITCH, S. (Orgs). Textos em representações sociais. $8^{\text {a }}$ Ed. Petrópolis, RJ: Vozes, 1995. 291 p.

MOSCOVICI, S. A representação social da psicanálise. Rio de Janeiro-RJ: Zahar Editores, 1978. 291p.

PÁDUA, Maria Tereza Jorge. Área de Proteção Ambiental. In: Direito Ambiental das Áreas Protegidas: O Regime Jurídico das Unidades de Conservação. Antônio Herman Benjamin (org.). Rio de Janeiro: Forense Universitária, 2001.

REIS, João Rodrigo Leitão dos e FREITAS, Minéia Santana de. Territorialidades e uso público dos recursos turísticos naturais na Amazônia Central. In: $1^{\circ}$ Congresso de Ecoturismo da Amazônia, 2008, Manaus/AM. Anais do $1^{\circ}$ Congresso de Ecoturismo da Amazônia. Manaus/AM : Departamento de Geografia - Universidade Federal do Amazonas, 2008.

REIS, João Rodrigo Leitão dos; PINHEIRO, Eduardo da Silva; MACEDO, Mariza Alves de. Evolução do desflorestamento (1990-2006) em Áreas Protegidas da Amazônia Central. In.: Anais do VIII Seminário de Atualização em Sensoriamento Remoto e Sistemas de Informações Geográficas aplicados a Engenharia Florestal, Curitiba, 07 a 09 de outubro de 2008; Organizadores: Attilio Antonio Disparati, João Roberto dos Santos. Curitiba: FUPEF, 2008.

SANTOS, R. F. Planejamento ambiental: teoria e prática. Oficina de textos, 2004. 184p.

SCHERL, L. M.; WILSON, A.; WILD, R.; BLOCKHUS, J.; FRANKS, P.; MCNEELY, J. A.; MCSHANE, T. O. As áreas protegidas podem contribuir para a diminuição da pobreza? Oportunidades e Limitações. IUCN, Gland, Suíça e Cambridge, Reino Unido, 2006. 37p.

SESSEGOLO, Gisele Cristina; PRIES, Daniele Cristina; ROCHA, Luis Fernando Silva da; ROCHA, Ricardo Pinto da; e ZAKRZEWSKI, Darci Paulo. Manejo da Caverna do Maroaga, Presidente Figueiredo/AM. IV Congresso Brasileiro de Unidades de Conservação (1.:2004:Curitiba). Anais. V 1. Curitiba: Fundação O Boticário de Proteção à Natureza: Rede Nacional Pró Unidades de Conservação, 2004.

TAKAHASHI, L. Y. e MILANO, M. S. Preferências e percepção dos visitantes em relação aos impactos de uso público no Parque Estadual Pico do Morumbi e na Reserva Natural Salto Morato. Turismo Visão e Ação. V. 11. Balneário Camboriú, 2002. In: http://siaiweb06.univali.br/seer/index.php/rtva/article/view/1239. Acesso em: 01/12/2009.

TAKAHASHI, L. Y.; MAGRO, T. C. \& BRAMBILLA, M. Seminário: Uso público em unidades de conservação. In: Anais do II Congresso Brasileiro de Unidades de Conservação. $3^{\circ}$ volume. Campo Grande: Rede Nacional Pró-Unidades de Conservação: Fundação O Boticário de Proteção da Natureza, 2002. p 50-64.

TAKAHASHI, Leide. Uso público em unidades de conservação. Cadernos de Conservação: ano 2. Número 2. Curitiba-PR: Fundação O Boticário de Proteção da Natureza, 2004.

VALLS, Josep-Francesc. Gestão integral de destinos turísticos sustentáveis. Rio de Janeiro: Editora FGV, 2006.

VIGNATI, Federico. Gestão de destinos turísticos: como atrair pessoas para pólos, cidades e países. Rio de Janeiro: Ed. Senac Rio, 2008. 256p.

Revista da ANPEGE. v. 6, 2010 (jan./dez.) 
WEARING, S. \& NEIL, J. Ecoturismo: impactos, potencialidades e possibilidades. $1^{\circ}$ Ed. Brasileira (Tradução Carlos David Szlak). Barueri-SP, 2001. 278p.

Recebido em junho de 2010

Aceito em dezembro de 2010 